\title{
Study on the Extensive Teaching of Micro-lecture Under the Background of Education Informationization
}

\author{
Wei Gan \\ School of Architecture and Urban Planning \\ Huazhong University of Science and Technology \\ Wuhan, China
}

\author{
Yanning Liu \\ School of Architecture and Urban Planning \\ Huazhong University of Science and Technology \\ Wuhan, China
}

\begin{abstract}
Based on the popularization and application of information technology in education system, the educational development model in the information era takes the application of digital resource in the teaching as breakthrough and constantly promotes knowledge to spread and communicate in various forms. Taking micro-lecture works of computer design competition of Chinese college students as example, this research explores the extensive teaching model and application strategy of micro-lecture under the background of "education informationization", including organizing modularized curriculum model, training systematic scientific thinking, creating pluralistic learning environment, cultivating diversified practical ability and so on, analyzes the opportunities and challenges that extensive teaching of micro-lecture confronts with and provides experience and reference for other microlecture design.
\end{abstract}

Keywords-education informationization; micro-lecture; extensibility; knowledge internalization

\section{INTRODUCTION}

Under the premise of the continuous in-depth development of globalization and digitization in the 21 st century, China has started its transition from a traditional industrialized society to a modern economic society based on digital information. Digital new media has been applied to all walks of life, especially the transformation of modern education idea. Students are transformed from passive recipients of standardized education to active participants in the teaching process through information technology. As the important construction content in digital times, "micro-lecture" teaching has become the significant method for students to improve their learning ability and for teachers to enhance their teaching efficiency. However, in the development of micro-lecture in recent years, the excessive pursuit for the amount of microlecture has caused that the research and development lack systematicness and completeness. In micro-lectures, the teaching content is not detailed, teaching interaction in classroom is insufficient, and teaching content is not updated in time. In particular, the micro-lecture teaching lacks extensibility and cannot allow students to effectively and stably maximize the internalization of knowledge. In this context, how to comply with the development of the new century, reject stereotyped new media teaching, achieve the results which meet the requirements of course learning of students and extend and expand the teaching effect, improve the teacher's teaching efficiency, and cultivate students' learning accomplishment has become the important issues for its design. We must understand that a good micro-lecture not only can guide students to use creative thinking by means of new media digital images, enhance their interpretation and explanation for knowledge and cultural connotations, but also help them to improve creativity and aesthetic critique.

China Computer Design Competition is a specially national competition set in accordance with the innovation capacity improvement plan of related institution of higher learning promoted by the country and the policies that further deepen the educational reform in universities, further improve the quality of teaching, and enhance the quality of computer teaching, stimulate students' interest in computer learning, thereby cultivate innovative abilities and teamwork awareness among college students, train them to apply new multimedia technology to promote innovative ability in practice to create more innovation and entrepreneurship type, realistic type and inter-disciplinary talent. This research will select The Passage of Life-Flowers and Fruits, the first prize of the ninth microlecture works of computer design competition of Chinese college students, to make explanation. The content presented in this work is selected from the volume one of grade seven Biology Textbook of People's Education, and is the important and difficult knowledge in the biology course of ordinary middle school. The current course teaching has the problems of large differences in students' basics, traditional teaching methods and so on. It is necessary to carry out teaching reforms, so as to effectively cultivate the exploration spirit and innovation ability of middle school students. This work seeks to play a fundamental and leading role in cultivating students' scientific inquiry and practical abilities, developing habits of scientific thinking, understanding the significance of the harmonious development of human and nature, and raising awareness of environmental protection. 


\section{CONCEPT DEFINITION}

\section{A. Concept and Features of Micro-lecture}

Micro-lecture refers to the structured digital resource that applies new media technology to extract core learning content, produce teaching process and expand materials according to learners' cognitive rules. The classroom teaching video is an important component of the micro-lecture and plays a decisive role, covering the knowledge content of the curriculum teaching. In addition, the micro-lecture also includes supplementary teaching resources such as teaching design, courseware, material, teaching reflection, practice test, student feedback, and teacher commenting related to the course. Micro-lecture is different from the general teaching course or video, and it not only presents a thematic structural unit, but also involves the learning case or participation of students. If it is only a recorded teaching process, it does not meet the definition of "micro-lecture". Combining with the application of micro-lecture in the context of contemporary information, the following points are summarized: (1)The composition of micro-lecture: micro-lecture is a kind of new media teaching courses that regard teaching video as the core to constitute content and present the carrier, take the related micro-lecture teaching plan, teaching design, exercise, knowledge development, teaching reflection and students' summary as auxiliary teaching resources and has the planned, organizational and systematic characteristics. (2) Features of micro-lecture: the content is terse and forceful and the teaching time is often from 5 to 8 minutes. Compared with the wide meaning class, it has the characteristics of specific theme, core problem and simple core. (3) Content of micro-lecture: as a new type of learning resource, micro-lecture involves in various fields, originates from life and above life, and is an organic product of the combination of teaching resources and information technology. (4) Target of micro-lecture: the purpose of micro-lecture is to communicate and practice, cultivate students' initiative and motility in the process of learning cooperation and inspire their scientific and innovative thinking.

\section{B. The Extensibility of Micro-lecture}

The extensibility of micro-lecture refers to the extension and expand based on the course content. Combine with the actual situation of students through different problems and teaching activities, its target is to inspire and expand students' scientific thinking to achieve the purpose of training students' exploration and innovation ability. Knowledge will be stable and effective when it is internalized by the students themselves. Therefore, in the daily professional courses, teachers often actively lead students in practical activities and use various methods to enhance the extensibility of the classroom so as to improve the enthusiasm of active learning of learners. For example, in the classroom, the teacher gives students the opportunity to present learning results and broaden their horizons, and students share reviews with each other and learn from each other and s on. In addition to being able to greatly satisfy the demands of learners to learn about the basic knowledge of the classroom, micro-lecture also helps learners to consolidate and expand their knowledge and make up for the shortcomings in classroom teaching. This is an indispensable learning model for future learning.

However, with the development of informatization education in recent years, some teachers have shown deviations in the positioning of intensive teaching in the microlecture class, and some "one-sided" adaption and "blind" following appear. It cannot adapt to the application environment and teaching object, just combines teaching plan with video recording and lacks systematic resource development and application of micro-lecture. The teaching method of many micro-lectures still stays the general statement of single knowledge point or the improvement of test ability, and its extensibility and completeness still need to be improved. In the teaching content, it just pays attention to the improvement of knowledge and skill and lacks the cultivation of emotional attitude and value. To comply with the development tendency of "Internet +" ear, deepen education and teaching reform and enrich education and teaching recourse, China is vigorously holding micro-lecture events to improve this situation.

\section{Related Theoretical Basis of Extensibility of Micro-lecture}

1) Miniature theory of learning: Miniature learning ${ }^{1}$ refers to a learning style by using mobile communication technology to achieve two-way communication, it can make learners to study at anytime and anywhere. The miniature learning content carried by micro-media will present learning content and organize learning activities by means of practical and short content module, and put emphasis on learning relatively small, loosely connected and self-contained knowledge content or model within the limited time, not limited to mobile terminal as carrier which includes hand-held mobile devices, cell phones, PDA and others.

2) Constructivism theory: Constructivism theory ${ }^{2}$ is a brand new teaching idea deriving from the traditional teaching idea, and its distinctive features mainly reflect in the main body selection. The traditional teaching idea emphasizes that the learner shall be the main body and the behavioral actions shall be based on the situation that teacher imparts knowledge in the classroom and the students passively accept knowledge. It will be difficult for students to exercise their initiative and mobility. However, the constructivism theory advocates twoway transmission as the main focus and recipients as the center. It advocates that knowledge can be obtained through mutual assistance, autonomy, and innovation between teachers and students. Students are no longer the indoctrinate objects of knowledge, but are the active builders of the framework. Students actively and positively explore knowledge through their own subjective initiative and their own original knowledge and experience.

3) Theory of diminishing marginal utility: Theory of diminishing marginal utility refers to that "the utility unit will

Che Wenbo. New Dictionary of Contemporary Western Psychology: Jilin People's Publishing House, 2001-10.

Gao Wen, Xu Binyan, Wu Gang. Constructivism in Education: Educational Science Publishing House, 2008. 
gradually decrease when customer increases the consumer goods by each unit". Although this concept comes from economics, it can still give some ideas for the educational field under the information age. In the implementation of teaching, the frequency that students meet students will increase, which produces the diminishing returns of boundary effect and reduces students 'learning efficiency. However, the application of micro-lecture can effectively reduce the production of diminishing marginal utility. Because microlecture is a new teaching resource and has the features of strong flexibility and short time, it can effectively stimulate students' enthusiasm for learning, promote student self-study and cooperative learning, so that teachers have more time in the classroom to use effective teaching methods and achieve better teaching effect. ${ }^{3}$

\section{EXTENSIVE TEACHING MODEL OF MiCRO-LECTURE BASED ON "EDUCATION INFORMATIONIZATION"}

In the process of teaching, the extensive teaching model of micro-lecture based on "education informationization", as shown in "Fig. 1" takes the three main teaching links as the center, namely, students' preparation before class, cooperation practice of teachers and students in class, and consolidation of knowledge after class. It uses micro-lecture as the media vehicles to guide students to finish knowledge internalization and improve students' enthusiasm in independent study and modular learning. In the teaching mode, students arrange classroom knowledge through methods such as previewing and guiding, questions feedback, reconstructing and understanding conflicts, independent collaborative discussion, displaying results, and expanding extracurricular knowledge. Teachers construct the teaching framework, analyze the cognitive level, answer questions, and cooperate experimental explorations, organize classroom discussions, and make teaching reflections to carry out education and teaching for students. We should always implement the teaching idea of teacher-inspired guidance, students' substantive participation, and teacherstudent equality and interaction.

\footnotetext{
3 Gao Hongye. Microeconomics (Fifth Edition): China Renmin
} University Press, 2010: 58-60. 


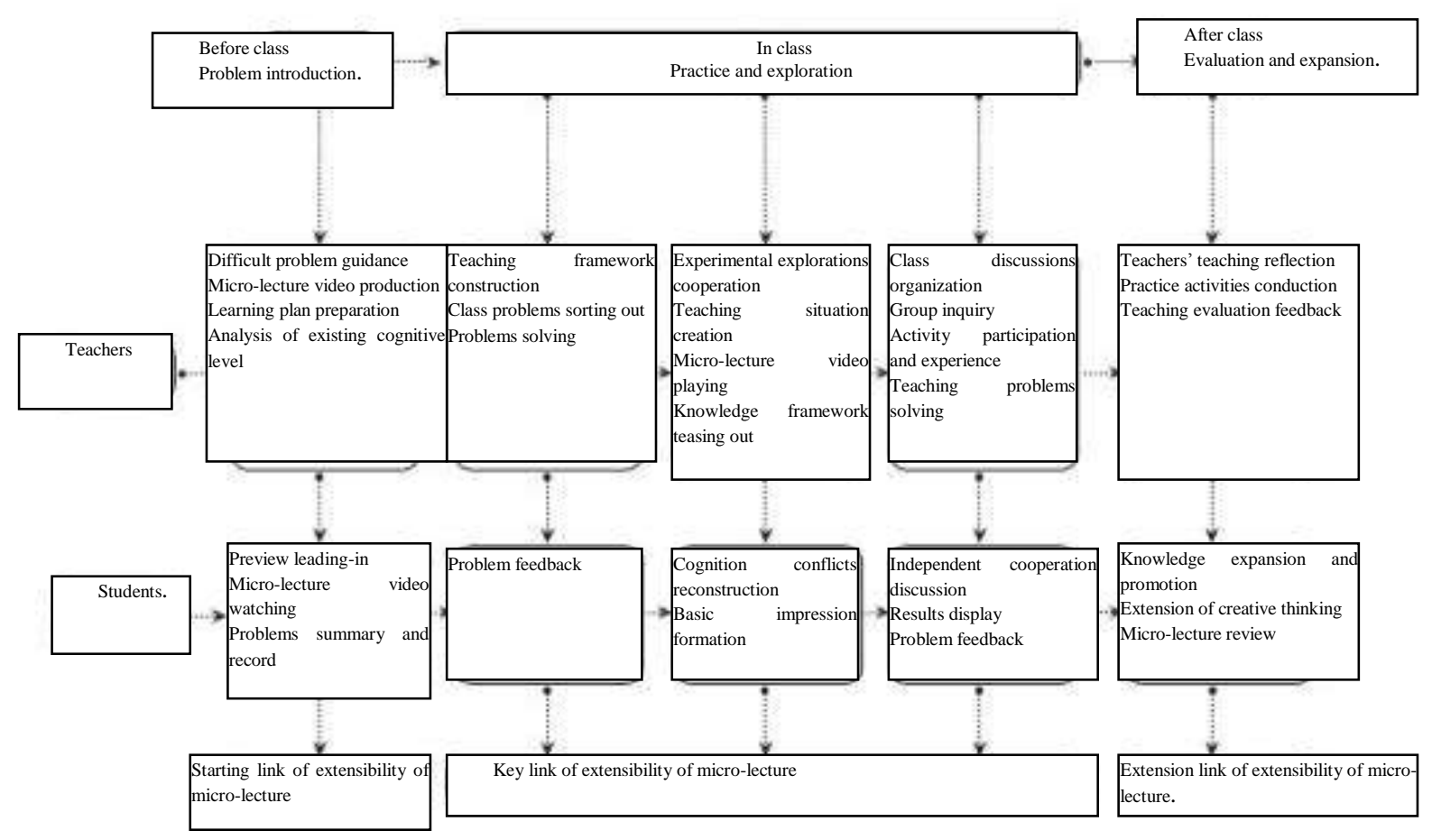

Fig. 1. Extensive teaching mode of micro-lecture.

\section{A. Students Should Prepare Lessons Independently Before Class}

This link is a starting link of the extensibility of knowledge in micro-lectures. On the basis of carefully teasing out students' existing cognitive level and teaching content, teachers will make teaching plans and micro-lecture videos before class. Students will independently learn related knowledge before class through the related questions, microlecture videos and learning tasks released by the teachers. This process can be called as the first internalization of knowledge. The original cognitive structure of students changes initially, and good cognition conflicts begin to appear. Students have got "correct concept" from the micro-lecture videos, and changed their original knowledge concept. Students will continue to question, explore, and investigate if the "new concept" cannot completely supersede the "former concept". Moreover, students can give full play to their self-awareness, become the master of learning, independently and creatively arrange the time and place of learning, actively find out and analyze problems, and summarize and record them, so that students can promptly get answers form teachers in class.

\section{B. Cooperation Practice of Teachers and Students in Class}

This link will further play a substantive role in the extensibility of micro-lecture. Students will complete basic knowledge learning independently before class. Relying on the diversified teaching situations created by the teachers in the physical classroom for students, students can further enhance their internalization of knowledge in class through collaborative experimental exploration, autonomous collaborative discussions, and other various practical activities.
Teachers will ask students to raise difficult problems in the process of self-regulated preparation in the first. Aiming at problems that are commonly fed back by students, they will create experiential teaching activities, and guide students to deeply perceive the gradual formation of the meaning through discussion, debate, and other forms of communication. The experiential learning activity can be a real experience in the classroom, also can be a virtual communication activity. The virtual experience can be accomplished through micro-lecture videos, and at the same time, the purpose that makes students to consolidate knowledge structure can be achieved. In an experiential activity, teachers should assist students in exploring, summarizing, and optimizing the knowledge system, and students should write and submit learning reports for problems feedback.

\section{Teachers and Students Will Consolidate Knowledge After Class}

Teachers should think about education and thinking after class, communicate with students through network microlecture platform and thought salon, sum up teaching results, evaluate students' practical activities, test students' leaning effects, and evaluate their learning outcomes. Students also need to organize their own performance in class, summarize gains and doubts, further develop extracurricular activities, effectively extend and promote internalization of knowledge. 


\section{APPLiCATION OF EXTENSIVE TEACHING MOdE OF MICRO-LECTURE BASED ON "EDUCATIONAL INFORMATIONIZATION"}

The micro-lecture works of The Passage of Life-Flowers and Fruits mainly includes six modules, namely, the structure of flowers, pollination and fertilization, the formation of fruit and seed, practicing what you learnt, having great fun, and extracurricular class. It mostly adopts multimedia assisted teaching, and uses vivid hand-drawn pictures, vivid animations, simple textual explanations and life-oriented teaching experiments, so as to enhance students' interest in learning and deepen students' understanding of teaching content. The class games and expansion of extracurricular knowledge can further guide students to develop their thinking. This works has achieved good results in the computer design competition of Chinese college students, and received recognition of many college teachers. The application of extensive teaching mode of micro-lecture based on "educational informationization" in the course of The Passage of Life-Flowers and Fruits is summarized as follows. It shows us that the following aspects are important if we want to successfully implement the extensive teaching of micro-lecture:

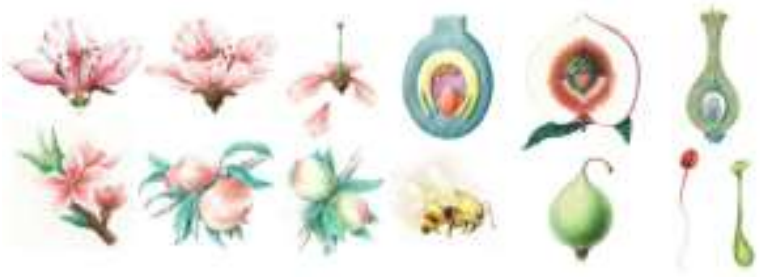

Fig. 2. Hand-drawn images in micro-lecture.

\section{A. Improving the Learning Atmosphere in a Diversified Way}

Krumm, a linguist, said that "successful classroom teaching should create more atmosphere situations so that students can use the knowledge materials they have learned". Effective teaching is inseparable from the creation of a diversified learning atmosphere, and has both vivid and intuitive features. It can not only touch students and promote the development of their thinking, but also help students to deepen their memory to form a solid knowledge experience. In the micro-lecture works of The Passage of Life-Flowers and Fruits, we selected cases that are close to life, refine the problem from them, and create an "immersive" learning atmosphere for students, which is conducive to improving students' knowledge building capabilities. Meanwhile, microlecture works makes use of multimedia displaying method, such as animation, audio-visual, and graphic texts, to support and extend the classroom knowledge. For example, Fig. 2 shows a hand-drawn graphic image for this set of microlecture.

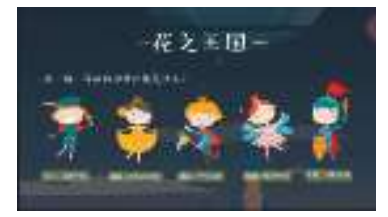

Fig. 3. Micro-lecture of "The Kingdom of Flowers".

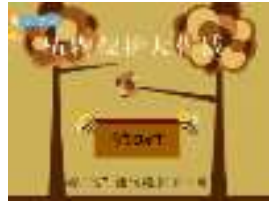

Fig. 4. Micro-lecture of "Fight for Plant Protection".

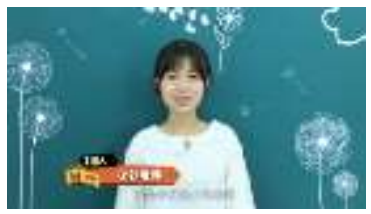

Fig. 5. Micro-lecture of "Class for Four Seasons Flowers".

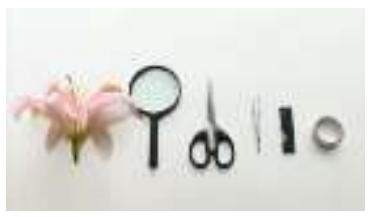

Fig. 6. Micro-lecture of "Experiment for Decomposition of Flowers".

\section{B. Increase Innovative Ability in Practice in a Diversified Way}

In the micro-lecture works of The Passage of LifeFlowers and Fruits, based on the teaching contents and characteristics of each section, students can participate in and experience different teaching activities voluntarily and actively to increase their practical and innovative abilities and to enhance the extension of knowledge. It will imperceptibly change the learning style of students and transmit the way of passive learning to an independent exploration and cooperation way. Taking into account the students' learning needs and knowledge level difference, we have specially added practice innovation activities of different topics, such as class introduction (the course from seed germination to flowering and fruiting), storytelling ("The Kingdom of Flowers") (Fig. 3), operation (extracurricular games of "Fight for Plant Protection") (Fig.4), theory-type ("Class for Four Seasons Flowers") (Fig.5), combination of theory and operation ("Experiment for Decomposition of Flowers") (Fig. 6), so that students can directly view the forms and hear the voices, and the intuitiveness of learning is greatly enhanced.

\section{Organization of Modular Course Model}

It is difficult to satisfy the internalization of knowledge by relying on limited classroom teaching. Therefore, in order to expand and promote the knowledge learned in class, a modular teaching organization is needed to provide extension and support for teaching knowledge. The micro-lecture works of The Passage of Life-Flowers and Fruits consists of six modules, namely, the structure of flowers, pollination and fertilization, the formation of fruit and seed, practicing what you learnt, having great fun, and extracurricular class. The first 3 modules are required for all students, and the last 3 modules are practice expansion modules. Each module supports and promotes each other step by step, further improving the 
teaching and enhancing the teaching effect. For example, after watching the core knowledge of flowers and fruits, students will review the knowledge that have learned through example explanation in the "practicing what you learnt" link of the fourth module, feel the different characteristics of the flowers and fruits in the four seasons by tracking the progress of the game through the fifth module, complete the consolidation of the core knowledge, and finally increase their practical and innovative abilities through extracurricular class, "Class for Four Seasons Flowers", "Handmade Dried Flower" and other links.

\section{Cultivation of Systematic Scientific Thinking}

Teachers effectively plan, organize and evaluate the teaching process in the micro-lecture class, which helps students to form a systematic scientific thinking and to clearly build framework of the classroom knowledge system. The cultivation of systematic scientific thinking is roughly divided into four stages, that is, classroom introduction, teaching design, teaching process, and classroom reflection. We need to constantly set up problems in the implementation process, practice and explore problems based on different teaching contents and needs, and finally reach a conclusion. Through these four steps, we can sort out students' scattered things in an orderly way, and form an overall and comprehensive section.

\section{CONCLUSION}

The extensive design of micro-lecture under the background of education informationization should not only satisfy the basic content of curriculum teaching, but also integrate students' cognition level and application requirements, and stably and effectively promote the internalization of knowledge, so as to maximize the use of learning resources. Through the study and discussion of extensive teaching mode of micro-lecture, the paper points out that it mainly penetrates into the three teaching links of "students' preparation before class, cooperation practice of teachers and students in class, and consolidation of knowledge after class.", showing a teaching trend from the shallower to the deeper, from the surface to the centre, from easy to difficult, and from the class to the extracurricular, and makes a deep demonstration combine with the micro-lecture works of The Passage of Life-Flowers and Fruits. This paper simply analyzes how to apply the extensibility of micro-lecture to "pre-class, in-class and post-class" from a small perspective. It is believed that in the future teaching practice, more teachers and students will follow this approach, try to experience the new teaching model, discuss and solve the existing problems together, so that the extensive teaching of the micro-lecture in the information environment will be more successful.

\section{REFERENCES}

[1] Luo Liping, Li Xiangyong, Jia Wei. The Design and Application of Flipped Classroom Based on "SPOC+Micro-Lecture+BYOD" - Taking "University Computer Foundation" Public Course for Example [J]. Journal of Southwest China Normal University (Natural Science Edition), 2017, 42 (08): 158-164. 罗丽苹, 李相勇, 贾巍. 基于 “SPOC+
微课+BYOD” 的翻转课堂设计与应用一一以 《大学计算机基础》 公共课为例[J].西南师范大学学报(自然科学版),2017,42(08):158-164

[2] Sun Hua. Effectively Extend and Promote Internalization - Thoughts on Extensive Teaching of High School Mathematics [J]. Correspondence of the Teaching of Mathematics, 2017 (21): 56-57. 孙华.有效延展,促进 内化一一高中数学延展性教学的几点思考 [J].数学教学通 讯,2017(21):56-57.

[3] Ke Zhenyun. Study on Design and Development of Information Technology Microlecture in High School under Mobile Learning Environment [D]. Sichuan Normal University, 2017. 柯珍芸. 移动学习 环境下的高中信息技术微课设计开发研究[D].四川师范大学,2017.

[4] Xu Yunchun. New Trends in Visual Art Education: A Study of New Media Arts Curriculum and Teaching in Middle School in the Digital Age [D]. East China Normal University, 2015. 徐耘春. 视觉艺术教育 的新动向: 数字时代背景下的中学新媒体艺术课程与教学研究 [D] 华东师范大学, 2015 .

[5] Zhu Jing, Su Xiaojun. The Construction and Application of Micro-class Mode of Instruction - - With a Focus on College English Visual-auraloral Course [J]. Computer-Assisted Foreign Language Education in China, 2015 (05): 21-25. 朱京,苏晓军.认知语言学视域下的微课教学 模式构建与应用一一以大学英语视听说课程为例 $[J]$. 外语电化教 学,2015(05):21-25.

[6] Che Wenbo. New Dictionary of Contemporary Western Psychology Jilin People's Publishing House, 2001-10. 车文博, 当代西方心理学 新词典: 吉林人民出版社, 2001-10

[7] Gao Wen, Xu Binyan, Wu Gang. Constructivism in Education: Educational Science Publishing House, 2008. 高文, 徐斌艳, 吴刚主 编. 建构主义教育研究: 教育科学出版社, 2008

[8] Gao Hongye. Microeconomics (Fifth Edition): China Renmin University Press, 2010: 58-60. 高鸿业. 西方经济学（微观部分）第 五版：中国人民大学出版社，2010 年：58-60 